\title{
PENGARUH NPL, LIKUIDITAS, DAN RENTABILITAS TERHADAP CAR PADA BPR KONVENSIONAL SKALA NASIONAL DI INDONESIA
}

\author{
Ni Putu Sinta Wira Putri ${ }^{1}$ \\ I Made Dana ${ }^{2}$ \\ ${ }^{1,2}$ Fakultas Ekonomi dan Bisnis Universitas Udayana, Bali, Indonesia \\ e-mail: sintawiraputri12@gmail.com
}

\begin{abstract}
ABSTRAK
Penelitian ini dilakukan untuk menganalisis pengaruh Non Performing Loan (NPL), Loan to Deposit Rasio (LDR), Return on Equity (ROE), dan Return on Assets (ROA)terhadap Capital Adequacy Ratio (CAR) secara parsial pada BPR Konvensional skala Nasional di Indonesia periode November 2014 - 2016. Metode pengumpulan data yang digunakan adalah observasi non partisipan. Sumber data dalam penelitian ini ialah data sekunder yang diakses di web resmi Bank Indonesia (BI). Teknik analisis datayang digunakan ialah regresi linier berganda yang diolah dengan program SPSS dengan teknik penentuan sampel sensus. Penelitian ini menemukan hasil bahwa NPL dan ROA berpengaruh positif signifikan terhadap CAR. LDR berpengaruh positif namun tidak signifikan terhadap CAR, serta ROE berpengaruh negatif signifikan terhadap CAR.
\end{abstract}

Kata Kunci: NPL, likuiditas, rentabilitas, CAR, BPR.

\begin{abstract}
This study was conducted to analyze the effect of non-performing loans (NPL), Loan to Deposit Ratio (LDR), Return on Equity (ROE) and Return on Assets (ROA)of the Capital Adequacy Ratio (CAR) partially on a national scale Conventional BPR in Indonesia during the period November 2014 - 2016. The data collection method used is a non-participant observation. Sources of data in this research is secondary data that is accessed on the official website of Bank Indonesia (BI). The data analysis technique used is multiple linear regression were processed with SPSS program with census sampling technique. This study found that the results of NPL and ROA have significant positive effect on CAR. LDR have positive but not significant effect on CAR and ROE have significant negative effect on CAR.
\end{abstract}

Keywords: NPL, liquidity, rentability, $C A R, B P R$. 


\section{PENDAHULUAN}

Perbankan adalah sebuah lembaga keuangan yang berfungsi sebagai perantara antara pihak yang memiliki kelebihan dana dengan pihak yang mengalammi kekurangan dana, selain itu perbankan juga berfungsi menjadi media untuk memperlancar lalu lintas pembayaran (Veithzal dkk., 2007:109). Bank menghimpun dana dari berbagai sumber dalam melaksanakan kegiatan operasionalnya. Dana tersebut didapat dari modal utama maupun dari modal pemilik. Memiliki modal yang cukup memadai menjadi sesuatu yang penting bagi sebuah bank untuk dapat menjaga kepercayaan masyarakat kepada kondisi sebuah bank, memfasilitasi perkembangan di kemudian hari, dan mengantisipasi kerugian yang mungkin terjadi.

Ketentuan Peraturan Bank Indonesia No. 15/12/PBI/ 2013 pasal 2 ayat 3 menyatakan bahwa persediaan modal minimum bagi sebuah bank tak terkecuali bagi bank umum adalah bagi sebuah bank yang memiliki satu peringkat profil risiko minimal memiliki modal 8 persen dari ATMRnya dan akan semakin meningkat apabila peringkat risikonya meningkat pula. Pengukuran pemenuhan permodalan bank dapat dihitung dengan alat ukur yang disebut CAR atau Capiital Adeuqacy Ratio. Rasio CAR dapat dihitung berdasarkan total modal bank serta total ATMR sebagai pembobotnya. Fungsi rasio CAR adalah untuk mengetahui kemungkinan risiko kerugian yang akan dihadapi oleh sebuah bank dengan mengetahui kecukupan modalnya yang diukur dalam persentase.

Kerangka Basel II memiliki empat elemen penting, yaitu yang pertama menjaga rasio kecukupan modal (CAR) untuk sektor perbankan. Kedua 
Ni Putu Sinta Wira Putri, Pengaruh NPL, Likuiditas, dan Rentabilitas...

menyesuaikan keputusan kecukupan modal berkaitan dengan instrumen hutang jangka panjang sesuai dengan Basel II. Ketiga memperkenalkan modal penyangga konservasi, sehingga melarang distribusi keuntungan bagi bank dengan CAR. Terakhir yaitu menyesuaikan perhitungan peraturan kecukupan modal bank (Hafizi dan Bushi, 2014).

Berdasarkan publikasi statistik pada website resmi Badan Pusat Statistik (BPS), Indonesia memiliki enam jenis bank yaitu Bank Pemerintah Daerah, Bank Persero, Bank Umum Syariah, Bank Asing dan Campuran, Bank Swasta Nasional, serta BPR Konvensional. Jumlah bank di Indonesia pada tahun 2014 secara berturut - turut adalah 4;26;56;12;21; dan 1637. BPR Konvensional mempunyai jumlah tertinggi yaitu 93.22 persen dari keenam jenis bank tersebut, maka dari itu penelitian ini dilakukan pada BPR konvensional di Indonesia.

Menurut Otoritas Jasa Keuangn (OJK), prinsip yang dianut BPR adalah prinsip syariah yang menjalankan kegiatan perbankannya secara konvensional namun tidak mnenjalankan jasa aliran pembayaran. Maka dapat disimpulkan bahwa ruang lingkup aktivitas BPR jauh lebih kecil daripada aktivitas yang dilakukan oleh bank umum. Selain itu modal awal berdirinya sebuah BPR relatif lebih rendah daripada bank umum (Rubyana, 2016).Dengan melihat kegiatan usaha yang dilakukan oleh BPR, maka dapat diketahui bahwa BPR merupakan lembaga yang penting bagi perekonomian Indonesia dan penting diketahui perkembangan kecukupan modalnya.

Perkembangan CAR pada BPR Konvensional Skala Nasional di Indonesia pada bulan November tahun 2014 - 2016 menunjukkan bahwa perolehan rata-rata 
CAR pada BPR Konvensional mengalami peningkatan berturut - turut dari tahun 2014 sampai dengan 2016 dengan presentase 26.08 persen pada tahun 2014, 27.12 pada tahun 2015, dan 28.68 persen pada tahun 2016. Namun, meskipun rata - rata CAR dari 33 provinsi tersebut meningkat, ternyata setiap provinsi memiliki presentase CAR yang berfluktuasi setiap tahunnya.

Terlihat pula dari 33 provinsi yang ada, terdapat empat provinsi yang mengalami penurunan CAR pada tiga tahun terakhir. Provinsi tersebut adalah Maluku Utara, Sulawesi Selatan, Banten, dan Jambi. Hal tersebut menunjukkan bahwa kinerja BPR Konvensional di Indonesia tidak seluruhnya mengalami peningkatan, sehingga penting untuk dilakukan peneltian lebih mendalam berkenaan dengan apa sajakah faktor yang dapat mempengaruhi terjadinya penurunan persentase CAR pada BPR konvensional. Beberapa faktor yang mempengaruhi pencapaian rasio kecukupan modal adalah rentabilitas, likuiditas serta kredit bermasalah atau Non Performing Loan (NPL).

NPL dapat dijelaskan sebagai sebuah kesulitan bagi seorang debitur untuk melakukan pelunasan atas kredit yang dilakukan yang disebabkan oleh faktor eksternal maupun kesenjangan diluar batas kendali debitur tersebut (Siamat, 2005:358). NPL yang semakin besar menandakan bahwa semakin banyaknya kredit bermasalah sehingga berdampak pada semakin tingginya risiko yang dihadapi oleh bank, begitu juga sebaliknya (Sudirman, 2013;204). Risiko kredit yang ditanggung bank akan dicerminkan melalui peningkatan NPL. NPL mempunyai korelasi yang positif terhadap tunggakan bunga kredit. NPL yang 
Ni Putu Sinta Wira Putri, Pengaruh NPL, Likuiditas, dan Rentabilitas...

sehingga akan mengakibatkan turunnya tingkat bunga dan diikuti oleh penurunan CAR.

Hasil penelitian sbeelumnya yang juga meneliti mengenai pengaruh NPL terhadap rasio kecukupan modal yang diukur dengan CAR dilakukan oleh Anjani dan Purnawati (2014) yang menemukan bahwa tidak adanya pengaruh signifikan antara NPL terhadap CAR. Hasil temuan lainnya oleh Winda dkk., (2016) serta Nuviyanti dan Herlanto (2014) menemukan bahwa terdapat pengaruh positif yang signifikan anatara NPL terhadap CAR. Mei Cai dan Zhonglin (2014) juga meneliti pada bank- bank Cina pada masa reformasi di Cina menghasilkan bahwa adanya pengaruh negatif yang signifikan antara NPL terhadap CAR. Ali Shingjergji (2013) menemukan bahwa rasio kecukupan modal (CAR) secara negatif namun tidak signifikan terkait dengan rasio NPL.

Rasio likuiditas di dalam dunia perbankan umumnya menggunakan alat ukur yang disebut LDR atau Loan to Dposit Ratoi(Sudirman, 2013:185). LDR merupakan rasio keuangan terkait aspek likuiditas pada perusahaan perbankan. Beberapa penelitian telah dilakukan sebelumnya, seperti penelitian ilmiah yang dilakukan oleh Anjani (2014) mengemukakan bahwa terdapat pengaruh yang negatif dan signfiikan antara LDR dengan rasio CAR, sedangkan Abdalla dan Samer (2013) melakukan penelitian pada bank komersial di Yordania di Amman Stock Exchange periode 2000-2008 yang menghasilkan bahwa CAR memiliki hubungan positif signifikan dengan risiko likuiditas.

Rentabilitas menunjukkan kemampuan suatu bank dalam menghasilkan laba yang menjadi modal milik sendiri. (Husnan, 2012:76). Rentabilitas dapat 
diproksikan dengan rasioReturn On Eqiuity (ROE) dan Retun On Asset (ROA). Menurut Riadi, (2016:187), ROE dihitung berdasarkan perbandingan laba setelah pajak terhadap modal inti dikali dengan 100 persen. Anjani (2014) dan Abdalla dan Samer (2013) melakukan penelitian mengenai pengaruh ROE terhadap CAR menemukan bahwa ROE berpengaruh negatif signifikan dengan CAR, berbeda dengan Batavia et al. (2013) menemukan bahwa ROE berpengaruh positif signifikan dengan CAR. Penelitian lain dilakukan oleh Adler dan Archie (2015) tentang penerbitan obligasi pada perbankan pada PT Finansial Bisnis Informasi periode 2008 - 2012 menghasilkan bahwa ROE berpengaruh negatif signifikan terhadap CAR.

Rasio ROA juga dapat digunakan untuk menghitung rentabilitas. ROA adalah laba sebelum pajak yang dibagi dengan total aset bagi sebuah bank pada periode tertentu dikali seratus persen. Ketentuan SENo.13/24/DPNP menyatakan bahwa batas minimal ideal ROA yang dimiliki sebuah bank yakni 1,5 persen. Penelitian terdahulu yang meneliti terhadap hubungan antara ROA dengan CAR dilakukan oleh Winda dkk.,(2016) bahwa ROA berpengaruh negatif signifikan terhadap CAR.Penelitian oleh Sulistyorini (2011) dan Sefri (2010) menghasilkan hal yang berbeda bahwa tidak terdapat pengaruh signifikan antara ROA dengan CAR.

Berdasarkan pemaparan di atas maka disimpulkan bahwa terdapat pengaruh LDR, NPL, ROA dan ROE terhadap CAR. Pembahasan tersebut menjadi penting untuk diteliti lebih lanjut, terkait dengan kredit macet, likuiditas, dan rentabilitas yang berpengaruh pada kecukupan modal sebuah bank. 
Ni Putu Sinta Wira Putri, Pengaruh NPL, Likuiditas, dan Rentabilitas...

Rumusan masalah dalam penelitian ini adalah bagaimanakah pengaruh NPL, LDR, ROE, dan ROA terhadap CAR. Penelitian ini bertujuan guna mengetahuipengaruh NPL, LDR, ROA, dan ROE terhadap CAR. Penelitian ini diharapkan mampu memberikan manfaat teoritis bagi peneliti selanjutnya yang akan meneliti pada topik yang sejenis, serta memberikan manfaat praktis bagi pihak manajemen perbankan dalam membuat keputusan maupun kebijakan.

\section{Kecukupan Modal (CAR)}

Kecukupan modal merupakan aspek yang mengukur apakah modal yang dimiliki oleh suatu bank telah memadai untuk menunjang kegiatan operasionalnya. Menurut Dian (2011) kecukupan modal merupakan salah satu indikator kemampuan bank dalam menutupi penurunan aktiva sebagai akibat kerugian yang diderita bank dan digunakan untuk mengukur kemampuan Bank dalam memenuhi kewajiban jangka pendeknya pada saat ditagih. Dengan kata lain pihak bank dapat membayar kembali pencairan dana deposannya pada saat ditagih serta dapat mencukupi permintaan kredit yang telah diajukan.

Tingkat kecukupan modal ini digunakan untuk menjaga kepercayaan masyarakat terhadap kinerja bank. Faktor utama yang cukup memengaruhi jumlah modal bank adalah jumlah modal minimum yang ditentukan oleh penguasa moneter yang biasanya merupakan wewenang bank sentral. Modal bank yang memadai diperlukan untuk meningkatkan ketahanan dan efisiensi di era deregulasi saat ini. Jumlah modal yang memadai memegang peranan penting dalam memberikan rasa aman kepada calon atau para nasabah, namun 
masih terdapat perbedaan cara dalam menentukan tingkat permodalan yang sehat.

Tingkat kecukupan modal dalam penelitian ini diproksikan dengan CAR. CAR adalah rasio kecukupan modal bank atau merupakan kemampuan bank dalam permodalan yang ada untuk menutup kemungkinan kerugian di dalam perkreditan atau dalam perdagangan surat-surat berharga. CAR menunjukkan seberapa besar modal bank telah memadai untuk menunjang kebutuhannya dan sebagai dasar untuk menilai prospek kelanjutan usaha bank bersangkutan (Wulan, 2011).

Dari berbagai pengertian di atas dapat disimpulkan bahwa rasio kecukupan modal minimum yang harus ada pada setiap bank sebagai pengembangan usaha dan penampung risiko kerugian usaha bank, rasio ini merupakan pembagian dari modal (modal inti dan modal pelengkap) dengan total ATMR. ATMR merupakan penjumlahan ATMR aktiva neraca (aktiva yang tercantum dalam neraca) dan ATMR aktiva administratif (aktiva yang bersifat administratif).

\section{Perbankan}

Perbankan telah berkembang selama bertahun-tahun karena meningkatnya persaingan, kemajuan teknologi, produk baru dan meningkatnya permintaan pelanggan. Namun, terlepas dari kemajuan tersebut, sektor perbankan harus menghadapi banyak kesulitan dalam operasi sehari-hari. Bank harus menghadapi risiko keuangan dan non-keuangan di lingkungan yang tidak menentu dan risiko 
seperti ini merupakan ancaman bagi bank jika tidak dikelola dengan baik (Maryam et al., 2015).

Ketentuan Undang - Undang Nomor 10 tahun 1998 tentang Perbankan, perbankan adalah segala sesuatu yang menyangkut tentang bank mencakup kelembagaan, kegiatan usaha, serta cara dan proses dalam melaksanakan kegiatan usahanya, sedangkan bank adalah badan usaha yang menghimpun dana dari masyarakat dalam bentuk simpanan dan menyalurkannya kepada masyarakat dalam bentuk kredit dan atau bentuk - bentuk lainnya dalam rangka meningkatkan taraf hidup rakyat banyak. Kasmir (2014:24) memaparkan dalam pembicaraan sehari - hari, bank dikenal sebagai lembaga keuangan yang kegiatan utamanya menerima simpanan giro, tabungan, dan deposito. Berdasarkan uraian diatas, maka dapat disimpulkan bahwa bank merupakan lembaga yang bergerak dalam bidang keuangan, artinya usaha perbankan selalu berkaitan dengan masalah bidang keuangan. Usaha perbankan meliputi tiga kegiatan utama yaitu menghimpun dana, menyalurkan dana, dan memberikan jasa bank lainnya.

\section{Permodalan Bank}

Menurut Sudirman $(2013 ; 91)$ Modal bank adalah sebuah cadangan dana yang dimiliki bank apabila mengalami kesulitan. Semakin tinggi jumlah modal yang dimiliki bank akan semakin baik untuk pertumbuhan bank meskipun modal yang dimiliki telah melebihi aturan yang dikeluarkan oleh bank sentral. Modal bank terdiri dari modal inti yaitu laba ditahan, setoran modal pemilik bank,cadangan umum, laba tahun berjalan, dan modal pelengkap seperti revaluasi 
aktiva, agio saham, dan good will. Frederic (2011;292) menyatakan modal bank dapat berguna sebagai pelindung mengantisipasi turunnya nilai aset serta menjadikan bank insolven.

\section{Non performing loan (NPL)}

Aset adalah suatu yang mampu menimbulkan aliran kas positif atau manfaat ekonomi lainnya. Berdasarkan Surat Keterangan Direksi Bank Indonesia No.26/22/KEP DIR tanggal 29 Mei 1993 tentang Kualitas Aktiva Produktif dan Pembentukan Penyisihan Aktiva Produktif, disebutkan bahwa penanaman dana bank pada aktiva produktif wajib sesuai dengan prinsip penanaman dana dan kesiapan bank dalam menanggung kemungkinan timbulnya risiko kerugian dalam penanaman dana tersebut.

Menurut Dian (2011) kualitas aset adalah semua aktiva total rupiah yang dimiliki bank dengan maksud untuk memperoleh penghasilan yang diharapkan. Salah satu perhitungan pada rasio kualitas aktiva yang digunakan menurut SEBI/No.7/10/DPNP tgl 13 Maret 2005 salah satunya adalah NPL. NPL adalah rasio yang membandingkan antara total kredit bermasalah terhadap total kredit yang disalurkan dalam bentuk presentase. Semakin rendah tingkat rasio NPL maka tingkat kredit bermasalah yang terjadi juga akan semakin rendah. Hal ini berarti semakin baik kondisi sebuah bank dan sebaliknya apabila semakin tinggi tingkat rasio NPL, maka semakin besar pula risiko kredit yang ditanggung oleh pihak bank (Andreani dan Erick, 2016). 
Rasio NPL menunjukkan kualitas aktiva kredit yang jika kolektibilitasnya kurang lancar, diragukan dan macet dari total kredit secara keseluruhan maka bank tersebut menghadapi kredit bermasalah. Meningkatnya jumlah penyaluran kredit akan menyebabkan meningkatnya NPL yang juga disertai meningkatnya beban, hal ini tentu saja akan mempengaruhi pertumbuhan modal. Besarnya beban operasional dan meningkatnya NPL juga mempengaruhi perkembangan modal. Ketentuan Peraturan Bank Indonesia Nomor 6/10/PBI/2004 tanggal 12 April 2004 tentang Sistem Penilaian Tingkat Kesehatan Bank Umum, semakin tinggi nilai NPL (diatas 5 persen) maka bank tersebut tidak sehat. NPL yang tinggi menyebabkan menurunnya laba yang akan diterima oleh bank.

NPL yang semakin tinggi akan mengakibatkan modal yang tersedia di bank semakin menipis. Meningkatnya jumlah kredit yang macet tentu saja akan mempengaruhi jumlah modal yang tersedia untuk membiayai kegiatan operasional bank. Kredit macet membuat berkurangnya pendapatan yang akan diterima oleh bank sehingga bank akan menggunakan modal yang ada untuk membiayai kegiatan operasionalnya. Semakin sering terjadi kemacetan maka modal bank lama kelamaan akan terkikis dan habis.

\section{Likuiditas}

Kasmir (2013:286) mengatakna bahwa rasio likuiditas digunakan untuk mengetahui kemampuan bank memenuhi kewajibannya dalam jangka pendek saat jatuh tempo. 
Kredit dapat dikatakan likuid jika pada saat ditagih bank mampu membayar.Dalam penelitian ini, rasio likuiditas yang digunakan adalah LDR. Menurut Kasmir (2013:319) LDR adalah rasio yang digunakan dalam mengukur kemampuan bank melakukan pembayaran kembali atas kewajibannya kepada nasabah yang menghimpun dana yang disalurkan melalui kredit - kedit yang diberikan kepada debitur. Rasio LDR yang semakin tinggi menunjukkan tingkat likuiditas yang dimiliki juga semakin tinggi.

Pemilihan rasio LDR disebabkan berdasarkan teori yang dikemukakan oleh Totok (2015:140) yang menyatakan bahwa salah satu indikator atau ukuran yang dapat digunakan untuk mengetahui tingkat likuiditas bank adalah LDR.

Indikator dalam menilai kesehatan likuiditas bank salah satunya dinyatakan dalam rasio LDR. Penilaian likuiditas dilakukan untuk mengetahui kesanggupan manajemen risiko likuditas bank dan mengetahui kemampuan bank dalam menjaga tingkat likuiditas yang optimal. LDR merupakan rasio yang paling banyak digunakan untuk melakukan penilaian kesehatan bank dalam hal total kredit yang disalurkan dengan dana yang dihimpun. Semakin tinggi rasio ini menunjukkan kemampuan likuiditas bank yang semakin rendah (Dian 2011). Total penyaluran kredit yang semakin tinggi dapat menyebabkan semakin tingginya nilai LDR suatu bank. Peningkatan LDR dapat menyebabkan nilai CAR menjadi semakin rendah karena dana yang dimiliki digunakan untuk menyalurkan kredit. 
Ni Putu Sinta Wira Putri, Pengaruh NPL, Likuiditas, dan Rentabilitas...

\section{Rentabilitas}

Menurut Kasmir (2013:297) rentabilitas merupakan rasio yang digunakan untuk mengukur tingkat efisiensi usaha dan profitabilitas yang dicapai oleh bank yang bersangkutan. Analisis rasio rentabilitas bank adalah alat untuk menganalisis atau mengukur tingkat efisiensi usaha dan keuntungan yang dicapai oleh bank yang bersangkutan. Penelitian ini dalam pengukuran rentabilitas dipilih pendekatan ROE dan ROA. Alasannya adalah karena ROA memperhitungkan kemampuan manajemen bank dalam memperoleh laba secara keseluruhan, sedangkan ROE menggambarkan kemampuan modal sendiri bank dalam menghasilkan laba.

Rasio ROE menunjukkan kemampuan modal sendiri untuk memperoleh laba. ROE dihitung dengan menggunakan laba bersih setelah dikurangi beban bunga dan pajak. Untuk modal yang digunakan dalam perhitungan ROE adalah modal sendiri yang digunakan untuk aktivitas bank. Bagi pemilik bank informasi mengenai rasio ROE menjadi sangat penting karena dapat mengetahui kemampuan manjemen dalam mengelola dana yang ada untuk memperoleh net income.

Husnan (2012:76) menyatakan bahwa ROE merupakan laba setelah bunga dan pajak yang dibandingkan dengan modal sendiri yang dirata - ratakan. Robert Ang, (2010) menyatakan bahwa ROE yaitu perbandingan antara laba setelah pajak atau Net Income Atfer Taxdengan keseluruhan modal sendiri yang dapat berupa setoran modal dari pemilik, laba ditahan, dan cadangan lainnya. Nilai ROE yang semakin tinggi menggambarkan bahwa kemampuan bank semakin efektif dalam 
menghasilkan laba bersih dari modal sendiri yang dimiliki. Dendawijaya (2009:118) menyatakan bahwarasio ROE dapat menunjukkan kemampuan bank dalammengelola modal yang ditanamkam untuk menghasilkan laba bersih .

ROA menggambarkan efektivitas bank ataupun perusahaan dalam mengelola aset optimalnya untuk menghasilkan laba. Perolehan laba yang semakin tinggi menyebabkan nilai ROA juga semakin tinggi, hal ini menunjukkan semakin efektifnya aktiva perusahaan dalam menghasilkan laba. pengukuran rentabilitas sangat penting dilakukan bagi sebuah bank karena tujuan yang ingin diraih oleh bank adalah nilai rentabilitasyang semakin tinggi. Nilai ROA menunjukkan kemampuan dari modal dalam bentuk aset perusahaan yang digunakan untuk memperoleh laba. Adapun rumusan hipotesis yang diangkat dalam penelitian ini adalah sebagai berikut:

$\mathrm{H}_{1}$ : NPL berpengaruh negatif dan signifikan terhadap CAR.

$\mathrm{H}_{2}$ : LDR berpengaruh negatif dan signifikan terhadap CAR.

$\mathrm{H}_{3}$ : ROE berpengaruh negatif dan signifikan terhadap CAR.

$\mathrm{H}_{4}$ : ROA berpengaruh positif dan signifikan terhadap CAR.

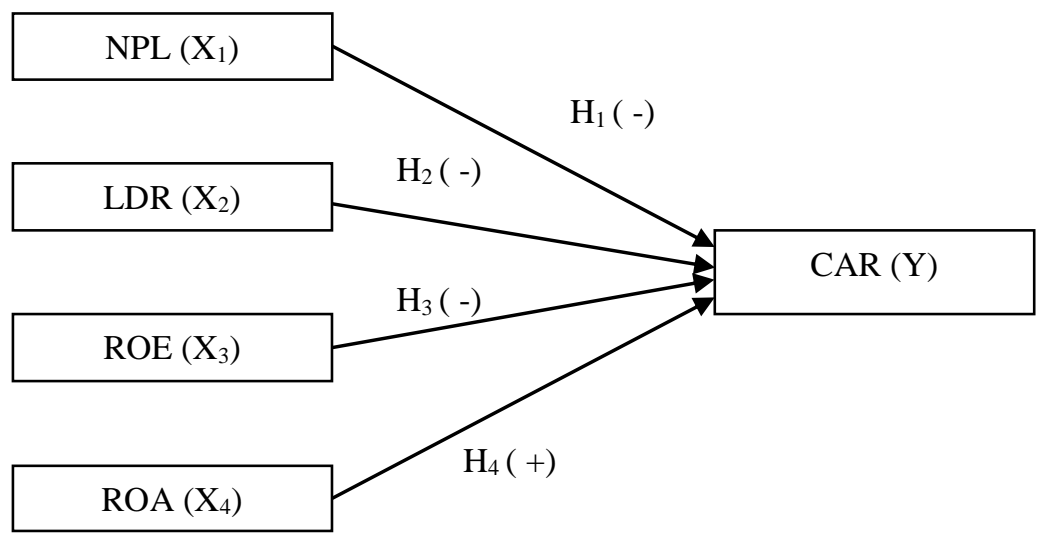

Gambar 1. Kerangka Konseptual 


\section{METODE PENELITIAN}

Penelitian menggunakan pendekatan kuantitatif dan pendekatan kausalitas (hubungan sebab akibat) yang bertujuan menyelidiki hubungan beberapa variabel bebas dengan variabel terikat. Seluruh BPR Konvensional yang terdapat di Indonesia di setiap provinsinya menjadi lokasi dalam penelitian ini. Data sekunder diperoleh dariwww.bi.go.id.Presentase NPL, LDR, CAR, ROE dan ROA BPR Konvesional di Indonesia bulan November tahun 2014 - 2016 digunakan sebagai objek penelitian.

Penelitian ini menggunakna dua jenis variabel yaitu variabel terikat $(\mathrm{CAR} / \mathrm{Y})$ dan empat variabel bebas yaitu NPL $\left(\mathrm{X}_{1}\right)$, LDR $\left(\mathrm{X}_{2}\right)$, ROE $\left(\mathrm{X}_{3}\right)$, dan ROA $\left(\mathrm{X}_{4}\right)$. Sebanyak 1.637 bank BPR yang merupakan seluruh bank BPR yang ada di seluruh provinsi di Indonesia digunakan sebagai populasi penelitian. Metode pengumpulan data yang dipakai ialah observasi non partisipan. Data kuantitatif CAR, NPL, LDR, ROE, dan ROA dari BPR Konvensional di Indonesia yang digunakan dalam penelitian ini diperoleh dari sumber sekunder.

Teknik yang digunakan untuk menganalisis data adalah regresi linier berganda yang diproses dengan bantuan SPSS. Definisi operasional masing masingvariabel yang digunakan dalam penelitian adalah variabel terikat yangdiproksikan dengan CAR dirumuskan dengan modal bank dibagi dengan aktiva tertimbang menurut risiko dikali 100 persen.Modal bank diperoleh dari penjumlahan modal inti dengan modal pelengkap, sedangkan aktiva tertimbang

menurut risiko diperoleh dari penjumlahan ATMR necara dengan ATMR rekening administratif. Variabel bebas yang diteliti ada empat yaitu NPL yang 
dirumuskan dengan kredit bermasalah dibagi dengan total kredit dikali 100 persen, LDR yang dirumuskan dengan total kredit yang disalurkan dibagi dengan total dana pihak ketiga dikali 100 persen, ROE dirumuskan dengan laba setelah pajak dibagi dengan modal sendiri yang dirata - ratakan dikali 100 persen, dan ROA yang dirumuskan dengan laba sebelum pajak dibagi dengan total aset dikali 100 persen.

\section{HASIL DAN PEMBAHASAN}

\section{Uji Autokorelasi}

Hasil perhitungan Uji Durbin-Watson tampak sebagai berikut.

Tabel 1.

Hasil Uji Autokorelasi

\begin{tabular}{|c|c|c|c|c|c|c|c|c|c|c|}
\hline \multirow[t]{2}{*}{ Model } & \multirow[t]{2}{*}{$\mathbf{R}$} & \multirow{2}{*}{$\begin{array}{c}\mathbf{R} \\
\text { Square }\end{array}$} & \multirow{2}{*}{$\begin{array}{c}\text { Adjusted } \\
\text { R } \\
\text { Square }\end{array}$} & \multirow{2}{*}{$\begin{array}{c}\text { Std. } \\
\text { Error of } \\
\text { the } \\
\text { Estimate }\end{array}$} & \multicolumn{5}{|c|}{ Change Statistic } & \multirow{2}{*}{$\begin{array}{c}\text { Durbin } \\
- \\
\text { Watson }\end{array}$} \\
\hline & & & & & $\begin{array}{c}c \text { R } \\
\text { Square } \\
\text { Change }\end{array}$ & $\begin{array}{c}\mathbf{F} \\
\text { Change }\end{array}$ & df1 & df2 & $\begin{array}{c}\text { Sig. F } \\
\text { Change }\end{array}$ & \\
\hline 1 & $.817^{\mathrm{a}}$ & .668 & .654 & 6.45297 & .668 & 47.295 & 4 & 94 & .000 & 2.104 \\
\hline
\end{tabular}

Berdasarkan tabel 1. di atas terlihat bahwa nilai Durbin - Watson adalah 2.104. Level signifikansi 5 persen, untuk $\mathrm{n}=99$ dan jumlah variabel bebas $(\mathrm{k})$ sebanyak $4, \mathrm{dL}=1.59$, dan $\mathrm{dU}=1.76$. Hal ini berarti nilai Durbin-Watson tersebut berada di antara (4-dU) dan (4-dL) yang menunjukkan model regresi linier berganda pada penelitian ini terbebas dari autokorelasi.

\section{Uji Multikolinieritas}

Metode untuk mengetahui adanya multikolinieritas dalam metode regresi adalah dengan melihat nilai tolerance dan Variance Inflation Factor (VIF). Pada tabel 2 disajikan hasil perhitungan nilai tolerance dan VIF dengan menggunakan program SPSS. 
Tabel 2.

Hasil Uji Multikolinieritas

\begin{tabular}{|c|c|c|c|c|c|c|c|c|}
\hline & \multirow[b]{2}{*}{ Model } & \multicolumn{2}{|c|}{$\begin{array}{c}\text { Unstandardized } \\
\text { Coefficients }\end{array}$} & $\begin{array}{l}\text { Standardized } \\
\text { Coefficients }\end{array}$ & \multirow[b]{2}{*}{$\mathbf{t}$} & \multirow[b]{2}{*}{ Sig. } & \multicolumn{2}{|c|}{$\begin{array}{l}\text { Collinearity } \\
\text { Statistics }\end{array}$} \\
\hline & & B & $\begin{array}{l}\text { Std. } \\
\text { Error }\end{array}$ & Beta & & & Tolerance & VIF \\
\hline 1 & (Constant) & 0.242 & 8.090 & & .030 & .976 & & \\
\hline & NPL & 1.596 & .166 & .694 & 9.619 & .000 & .678 & 1.476 \\
\hline & LDR & .057 & .096 & .043 & .594 & .554 & .670 & 1.492 \\
\hline & ROE & -.162 & .026 & -.656 & 6.131 & .000 & .308 & 3.244 \\
\hline & ROA & 4.9991 & .621 & .768 & 8.041 & .000 & .387 & 2.581 \\
\hline
\end{tabular}

Berdasarkan hasil olahan data yang ditampilkan pada tabel 2, menunjukkan bahwa koefisien tolerance lebih besar dari 0.10 dan VIF lebih kecil dari 10. Hal ini berarti tidak terdapat gejala multikolinieritas dari model regresi yang dibuat, sehingga model tersebut layak digunakan untuk memprediksi.

\section{Uji Heteroskedastisitas}

Model regresi tidak mengandung heteroskedastisitas bila probabilitas signifikansi variabel bebasnya terhadap nilai absolute residual statistik di atas $\alpha=$ 0,05. Hasil uji glejser ditunjukkan pada tabel 3 .

Tabel 3.

Hasil Uji Heteroskedastisitas (Uji Glejser)

\begin{tabular}{|c|c|c|c|c|c|c|}
\hline & \multirow[b]{2}{*}{ Model } & \multicolumn{2}{|c|}{$\begin{array}{c}\text { Unstandardized } \\
\text { Coefficients }\end{array}$} & \multirow{2}{*}{$\begin{array}{c}\begin{array}{c}\text { Standardized } \\
\text { Coefficients }\end{array} \\
\text { Beta } \\
\end{array}$} & \multirow[b]{2}{*}{$\mathbf{t}$} & \multirow[b]{2}{*}{ Sig. } \\
\hline & & B & Std. Error & & & \\
\hline \multirow[t]{5}{*}{1} & (Constant) & 5.862 & 5.211 & & 1.125 & .264 \\
\hline & NPL & .158 & .107 & .182 & 1.478 & .143 \\
\hline & LDR & -.025 & .062 & -.050 & -.407 & .658 \\
\hline & ROE & .013 & .017 & .142 & .778 & .439 \\
\hline & ROA & -.256 & .400 & -.104 & -.640 & .524 \\
\hline
\end{tabular}

Sumber: data diolah, 2017

Berdasarkan tabel 3diatas dapat dilihat bahwa semua variabel memiliki probabilitas signifikansi> 0,05 ini berarti pada model regresi tidak terjadi gejala heteroskedastisitas. 


\section{Analisis Regresi Linier Berganda}

Dalam model analisis regresi linier berganda yang digunakan sebagai variabel bebas adalah NPL, LDR, ROE, dan ROA sedangkan variabel terikatnya adalah CAR. Hasil rangkuman analisis regresi dapat dilihat pada tabel di bawah ini.

Tabel 4.

Rangkuman Hasil Penelitian

\begin{tabular}{lllll}
\hline $\begin{array}{l}\text { Variabel } \\
\text { Terikat }\end{array}$ & $\begin{array}{l}\text { Variabel } \\
\text { Bebas }\end{array}$ & $\begin{array}{l}\text { Koefisien } \\
\text { Regresi }\end{array}$ & t-hitung & Sig \\
\hline $\mathbf{Y}$ & $\mathrm{X}_{1}$ & 1.596 & 9.619 & 0.000 \\
& $\mathrm{X}_{2}$ & 0.057 & 0.594 & 0.554 \\
& $\mathrm{X}_{3}$ & -0.162 & -6.131 & 0.000 \\
& $\mathrm{X}_{4}$ & 4.991 & 8.041 & 0.000 \\
Constanta $=\mathbf{0 . 2 4 2}$ & & F Hitung $=47.295$ \\
R Square $=\mathbf{0 . 6 6 8}$ & & Signifikansi $=0.000$ \\
Adj R Square $=\mathbf{0 . 6 5 4}$ & & & \\
\hline
\end{tabular}

Sumber: data diolah, 2017

\section{Pengaruh NPL, LDR, ROE, dan ROA secara parsial terhadap CAR}

Untuk menguji hipotesis dalam penelitian ini maka digunakan uji t. Uji t digunakan untuk mengetahui pengaruh variabel bebas, yaitu NPL $\left(\mathrm{X}_{1}\right), \operatorname{LDR}\left(\mathrm{X}_{2}\right)$, $\operatorname{ROE}\left(\mathrm{X}_{3}\right)$, dan $\mathrm{ROA}\left(\mathrm{X}_{4}\right)$ secara parsial terhadap CAR (Y) BPR konvensional skala nasional di Indonesia periode 2014 - 2016. Uji t dilakukan dengan membandingkan nilai $t_{\text {hitung }}$ dengan nilai $t_{\text {tabel }}$ pada taraf signifikansi 0.05 dengan pengujian $\alpha=0.05 ; \mathrm{df}=\mathrm{n}-\mathrm{k}=99-4=95$, sehingga $\mathrm{t}_{\text {tabel }}(0.025 ; 95)$ adalah sebesar 1.984. Hasil analisis uji dapat dilihat pada tabel 4.

\section{Pengaruh NPL terhadap CAR}

Berdasarkan tabel 5 dapat diketahui bahwa besarnya $t_{\text {hitung }}=9.619>t_{\text {tabel }}=$ 1.984 dan probabilitas signifikansi sebesar $0.000<\alpha=0.05$, maka $\mathrm{H}_{0}$ ditolak dan $\mathrm{H}_{1}$ diterima. Hal ini berarti NPL berpengaruh positif dan signifikan terhadap CAR, 
hal tersebut dikarenakan kondisi ekonomi dan data yang diteliti pada penelitian ini memiliki kondisi yang berbeda dari teori.

Tabel 5.

\begin{tabular}{ccccc}
\multicolumn{4}{c}{ Nilai t-hitung dan t-tabel pada taraf signifikansi 5 persen } \\
\hline Variabel & t-hitung & t-tabel & Sig & Keterangan \\
\hline NPL $\left(\mathrm{X}_{1}\right)$ & 9.619 & 1.984 & 0.000 & Positif signifikan \\
$\operatorname{LDR}\left(\mathrm{X}_{2}\right)$ & 0.594 & 1.984 & 0.554 & Tidak signifikan \\
$\operatorname{ROE}\left(\mathrm{X}_{3}\right)$ & -6.131 & 1.984 & 0.000 & Negatif signifikan \\
$\operatorname{ROA}\left(\mathrm{X}_{4}\right)$ & 8.041 & 1.984 & 0.000 & Positif signifikan \\
\hline
\end{tabular}

Sumber: data diolah, 2017

Beberapa perusahaan perbankan pada periode tertentu memiliki nilai NPL dan CAR yang tinggi secara bersamaan, hal tersebut disebabkan karena adanya penambahan modal pada komponen modal bank. Penambahan tersebut bisa terjadi pada modal inti maupun modal pelengkap. Misalnya saja modal yang disetor oleh pemilik bank lebih besar nilainya dengan kredit macet yang terjadi, maka dana tambahan tersebut dapat menutupi kredit yang bermasalah. Sehingga kemampuan BPR dalam memenuhi kecukupan modalnya dan risiko kredit macet sama - sama mengalami peningkatan.

Pemaparan tersebut konsisten dengan penelitian yang dilakukan oleh Winda dkk., (2016) yang menyatakan bahwa NPL berpengaruh positif dan signifikan terhadap CAR. Namun, terdapat perbedaan hasil pada penelitian yang dilakukan oleh Anjani dan Purnawati (2014), Hendra dan Wisnu (2006), serta Andreani dan Erick (2016) yang menyatakan bahwa NPL tidak berpengaruh signifikan terhadap CAR. Hasil penelitian Puspa dkk (2015) yang menyatakan bahwa NPL berpengaruh positif namun tidak signifikan terhadap CAR serta penelitian Mei 
Cai dan Zhonglin (2014) yang menyatakan bahwa NPL berpengaruh negatif terhadap CAR.

\section{Pengaruh LDR terhadap CAR}

Berdasarkan tabel 5 dapat diketahui bahwa besarnya $t_{\text {hitung }}=0.594<t_{\text {tabel }}=$ 1.984 dan probabilitas signifikansi sebesar $0.554>\alpha=0.05$, maka $\mathrm{H}_{0}$ diterima dan $\mathrm{H}_{1}$ ditolak. Hal ini berarti LDR berpengaruh positif namun tidak signifikan terhadap CAR. Artinya pada saat LDR meningkat maka akan terjadi peningkatan pada CAR, namun berdasarkan hasil yang tidak signifikan dalam penelitian ini memiliki arti bahwa LDR tidak secara nyata berpengaruh terhadap CAR.

Hasil penelitian tersebut tidak sesuai teori dikarenakan kondisi data yang diolah berbeda dengan teori yang dijelaskan. Perbandingan jumlah kredit yang diberikan oleh BPR lebih sedikit dibandingkan dengan DPK, maka BPR tidak kekurangan dana dalam menyalurkan kredit. Modal BPR juga tidak dipengaruhi oleh kondisi tersebut. Pada saat CAR tinggi, pertumbuhan kredit bisa saja meningkat karena BPR dapat menyalurkan kredit lebih besar menggunakan modal. LDR berpengaruh tidak signifikan terhadap CAR dikarenakan pada saat LDR meningkat namun pertumbuhan kredit yang diberikan setiap tahunnya konstan, maka nilai riil modal tidak akan dipengaruhi.

Hasil penelitian ini sejalan dengan hasil penelitian yang diperoleh Chyntia (2012) yang menyatakan bahwa LDR tidak berpengaruh signifikan terhadap CAR. Namun, terdapat perbedaan hasil penelitian yang dilakukan oleh Anjani dan Purnawati (2014) dan Puspa dkk., (2015) yang menyatakan bahwa LDR 
berpengaruh negatif dan signifikan terhadap CAR. Penelitian yang dilakukan oleh Achmad dkk., (2016) juga tidak konsisten dengan hasil LDR berpengaruh negatif dan tidak signifikan terhadap CAR.

\section{Pengaruh ROE terhadap CAR}

Berdasarkan tabel 5 dapat diketahui bahwa besarnya $t_{\text {hitung }}=-6.131>\mathrm{t}_{\text {tabel }}=$ 1.984 dan probabilitas signifikansi sebesar $0.000<\alpha=0.05$, maka $\mathrm{H}_{0}$ ditolak dan $\mathrm{H}_{1}$ diterima. Hal ini berarti $\mathrm{ROE}$ berpengaruh negatif dan signifikan terhadap CAR. Hasil dari penelitian ini adalah ROE berpengaruh negatif dan signifikan terhadap CAR. Hasil tersebut menggambarkan bahwa hipotesis diterima. Semakin besar kemampuan BPR dalam menghasilkan laba, maka akan menurunkan kemampuan BPR dalam memenuhi kecukupan modalnya.

Hasil penelitian ini konsisten dengan penelitian yang dilakukan oleh Abdalla dan Samer (2013), Bokhari et al., (2012) serta Anjani dan Purnawati (2014) yang memperoleh hasil bahwa ROE berpengaruh negatif dan signifikan terhadap CAR. Namun, hasil penelitian tidak sesuai dengan penelitian yang dilakukan oleh Batavia et al., (2013) yang mendapatkan hasil bahwa ROE memiliki pengaruh positif dan signifikan terhadap CAR.

\section{Pengaruh ROA terhadap CAR}

Berdasarkan tabel 5dapat diketahui bahwa besarnya $\mathrm{t}_{\text {hitung }}=8.041>\mathrm{t}_{\mathrm{tabel}}=$ 1.984 dan probabilitas signifikansi sebesar $0.000<\alpha=0.05$, maka $\mathrm{H}_{0}$ ditolak dan $\mathrm{H}_{1}$ diterima. Hal ini berarti ROA berpengaruh positif dan signifikan terhadap 
CAR. Hasil tersebut menunjukkan bahwa hipotesis diterima. Saat ROA meningkat maka CAR juga mengalami peningkatan, hal ini berarti semakin efektif BPR dalam menghasilkan keuntungan, maka kemampuan BPR dalam memenuhi kecukupan modalnya juga semakin tinggi.

Hasil penelitian ini konsisten dengan penelitian yang dilakukan oleh Alvita dan Vivi (2014) serta Abdalla dan Samer (2013) yang menemukan hasil bahwa ROA berpengaruh positif dan signifikan terhadap CAR. Namun, hasil penelitian tidak sesuai dengan penelitian yang dilakukan oleh Ochei (2013) yang menyatakan bahwa ROA berpengaruh negatif terhadap CAR. Winda dkk., (2016) memperoleh hasil bahwa ROA mempunyai pengaruh negatif dan signifikan terhadap CAR serta Puspa dkk, (2015) menemukan bahwa ROA berpengaruh negatif namun tidak signifikan terhadap CAR.

\section{IMPIKASI HASIL PENELITIAN}

Melihat proporsi NPL BPR Konvensional Indonesia yang berada di atas 5 persen selama 3 tahun berturut - turut, maka sebaiknya manajemen BPR mengelola kredit dengan baik agar presentase kredit bermasalah berada di bawah 5 persen sesuai peraturan Bank Indonesia dengan cara menerapkan prinsip kehati - hatian dan lebih selektif dalam menyalurkan kredit kepada nasabah. Presentase LDR BPR Konvensional Indonesia selama 3 tahun berturut - turut berada di bawah 93.75 persen, maka predikat BPR dikatakan sehat menurut peraturan Bank Indonesia. Diharapkan manajemen BPR dapat mempertahankan predikat tersebut dan meningkatkan penyaluran kredit dengan mempertimbangkan jumlah DPK 
yang dihimpun. BPR juga diharapkan bisa memperkuat modal agar likuiditas bank selalu terjaga.

Penambahan periode penelitian dapat dilakukan oleh peneliti kedepannya yang mengangkat topik serupa diharapkan dapat menambah periode penelitian, menggunakan perusahaan perbankan yang lain, serta mengukur variabel lain yang dapat mempengaruhi Capital Adequacy Ratio.

\section{SIMPULAN DAN SARAN}

\section{Simpulan}

Kesimpulan yang dapat dibentuk dari hasil pembahasan penelitian ini adalah NPL berpengaruh positif dan signifikan terhadap CAR pada BPR Konvensional Skala Nasional di Indonesia periode 2014 - 2016, karena kondisi data dan perekonomian yang berubah pada periode tertentu. Kecenderungan lain yang terjadi karena adanya penambahan modal pada komponen modal bank. Penambahan tersebut bisa terjadi pada modal inti maupun modal pelengkap.

Adanya pengaruh yang positif namun tidak signifikan antara Loan to Deposit Ratio terhadap Capital Adequacy Ratiopada BPR Konvensional Skala Nasional di Indonesia periode 2014 - 2016, karena perbandingan jumlah kredit yang diberikan oleh bank lebih sedikit dibandingkan dengan DPK, maka bank tidak kekurangan dana dalam menyalurkan kredit.

Adanya pengaruh yang negatif dan signifikan antara Return on Equity terhadap Capital Adequacy Ratiopada BPR Konvensional Skala Nasional di Indonesia periode 2014 - 2016, karena pada saat laba meningkat, maka bank tidak 
perlu tambahan dana yang berasal dari modal. Sehingga pada saat presentase ROE meningkat, maka presentase CAR akan menurun untuk mengurangi idle funds.

Return on Assets berpengaruh positif dan signifikan terhadap Capital Adequacy Ratiopada BPR Konvensional Skala Nasional di Indonesia periode 2014 - 2016, karena pada saat profitabilitas bank meningkat, maka dana juga akan meningkat. Dana tersebut dapat dimanfaatkan sebagai modal oleh bank dan otomatis akan meningkatkan nilai CAR bank.

\section{Saran}

Saran yang dapat disampaikan dalam penelitian iniyaitu melihat proporsi NPL BPR Konvensional Indonesia yang berada di atas 5 persen selama 3 tahun berturut - turut, maka sebaiknya manajemen BPR mengelola kredit dengan baik agar presentase kredit bermasalah berada di bawah 5 persen sesuai peraturan Bank Indonesia dengan cara menerapkan prinsip kehati - hatian dan lebih selektif dalam menyalurkan kredit kepada nasabah.

Presentase LDR BPR Konvensional Indonesia selama 3 tahun berturut turut berada di bawah 93.75 persen, maka predikat BPR dikatakan sehat menurut peraturan Bank Indonesia. Diharapkan manajemen BPR dapat mempertahankan predikat tersebut dan meningkatkan penyaluran kredit dengan mempertimbangkan jumlah DPK yang dihimpun. BPR juga diharapkan bisa memperkuat modal agar likuiditas bank selalu terjaga.

Saran bagi peneliti selanjutnya yang mengangkat topik sejenis diharapkan dapat menambah periode penelitian, menggunakan perusahaan perbankan yang 
lain, serta mengukur variabel lain yang dapat mempengaruhi Capital Adequacy Ratio (CAR).

\section{REFERENSI}

Achmad Choerudin, Eny Yuniatun, dan Bambang Kusdiasmo. 2016. Pengaruh Non Performing Loan (NPL) dan Loan to Deposit Ratio (LDR) terhadap Return on Asset (ROA) dengan Capital Adequacy Ratio (CAR) sebagai Variabel Intervening. Probank, Jurnal Ekonomi dan Perbankan, 2(2) : 2847.

Ali Polat dan Hassan Al-khalaf. 2014. What Determines Capital Adequacy in the Banking System of Kingdom of Saudi Arabia? A Panel Data Analysis on Tadawul Banks. Journal of Applied Finance \& Banking, 4(5) : 27-43.

Ali Shingjergji. 2013. The Impact of Bank specific Variables on the Non Performing Loan Ratio in the Albanian Banking System. Research Journal of Finance and Accounting, 4(7) : 148-152.

Alvita Chatarine dan Putu Vivi Lestari. 2014. Pengaruh Kualitas Aktiva Produktif, BOPO terhadap ROA Dan CAR pada BPR Kabupaten Badung. E-Jurnal Manajemen Unud, 3(3) : 561-577.

Andreani Caroline Barus dan Erick. 2016. Analisis Faktor-Faktor yang Mempengaruhi Non Performing Loan pada Bank Umum di Indonesia. Jurnal Wira Ekonomi Mikroskil, 5(1) : 113-122.

Ang, Robert. 2010. Buku PintarPasar Modal Indonesia edisi 7. Jakarta: Media Soft Indonesia.

Archie Marlon Sapulete dan Adler Haymans Manurung. 2015. Pengaruh Penerbitan Obligasi Subordinasi dan Rasio Keuangan terhadap Profitabilitas Bank. http://www.finansialbisnis.com/. Diunduh pada 9 Mei 2017.

Ayu Anjani, Dewa dan Ni Ketut Purnawati. 2014. Pengaruh Non Performing Loan (NPL), Likuiditas, dan Rentabilitas terhadap Rasio Kecukupan Modal. E-jurnal Manajemen Universitas Udayana, 3 (4) : 1140-1155.

Badan Pusat Statistik. Bank dan Kantor Bank, 2010 - 2015. https://www.bps.go.id/linkTabelStatis/view/id/1856. Diunduh pada 10 Desember 2017.

Bank Indonesia. Kinerja BPR Konvensional Skala Nasional.http://www.bi.go.id/id/statistik/perbankan/bprkonvensional/indik atorutama/Default.aspx. Diunduh pada 22 Juli 2017. 
Batavia, Bala, Nandakumar Parameswar, Sree Rama Murthy, dan Cheick Wague. 2013. Avoiding A Liquidity Crunch: Do Pre-Bear Phase Bank Ratios Matter? Evidence fromA World-Wide Sample. Journal of Applied Economics and BusinessResearch, 3 (1) : 1-13.

Bokhari, Ijaz Hussain, Syed Muhamad Ali dan Khurram Sultan. 2012. Determinants of Capital Adequacy Ratio in Banking Sector: An EmpiricalAnalysis from Pakistan. Academy of Contemporary Research Journal, 2 (1) : 1-9.

Budisantoso, Totok dan Nuritomo. 2015. Bank dan Lembaga Keuangan Lain, Edisi 3. Jakarta: Salemba Empat.

Cynthia Edginarda. 2012. Analisis Pengaruh Rasio Rentabilitas dan Likuiditas terhadap Capital Adequacy Ratio (CAR) pada Bank Pemerintah di Indonesia Periode 2003-2010. Skripsi Sarjana Ekonomi pada Fakultas Ekonomi dan Bisnis Universitas Hasanuddin, Makassar.

Dendawijaya, Lukman. 2009. Manajemen Perbankan. Jakarta: Ghalia Indonesia.

Dian Faturrohman. 2011. Pengaruh Tingkat Likuiditas (LDR), dan Kredit Bermasalah (NPL) terhadap Tingkat Kecukupan Modal Bank Negara Indonesi Tbk. Jurnal UNDIP. http://elib.unikom.ac.id/files/ disk1/ 581/jbptunikompp-gdldianfaturr-29031-8-presenta- .pdf. Diakses pada 1 Mei 2017

Dickson Pastory dan Marobhe Mutaju. 2013. The Influence of Capital on Assets Quality Position of Bank in Tanzania. International Journal of Economics and Finance, 5(2), pp: 179-194.

Fathiyah, Andini dan Irni Yunita. 2015. Analisis Pengaruh Return on Asset (ROA), Return on Equity (ROE), Non Performing Loan (NPL), dan Loanto Deposit Ratio (LDR) terhadap Perbankan di Indonesia. eProceeding of Management, 2(2) : 1384 -1391.

Fitri Ruwaida. 2011. Analisis Laporan Keuangan Untuk Menilai Tingkat Kesehatan pada BPR Bank Klaten.Skripsi Sarjana Ekonomi pada Fakultas Ekonomi Universitas Negeri Yogyakarta, Yogyakarta.

Fitria Sakinah. 2013. Faktor-Faktor yang Mempengaruhi Capital Adequacy Ratio (CAR) pada Bank Syariah di Indonesia Periode Maret 2009 - Desember 2011. Skripsi. Sarjana Ekonomi Fakultas Ekonomi dan Bisnis Universitas Islam Negeri Syarif Hidayatullah, Jakarta.

Frederic S. Mishkin. 2011. Ekonomi Uang, Perbankan, dan Pasar Keuangan, Edisi 8 Buku 1. Jakarta: Salemba Empat.

Ghozali, Imam. 2013. Aplikasi Analisis Multivariate dengan Program SPSS 19. Semarang: Badan Penerbit Universitas Diponogoro. 
Hafizi, Denada dan Irjan Bushi. 2014. Banking Regulation of Western Balkan Countries. European Journal of Sustainable Development, 3(3) : 345-356.

Hendra Fitrianto dan Wisnu Mawardi. 2006. Analisis Pengaruh Kualitas Aset, Likuiditas, Rentabilitas, dan Efisiensi terhadap Rasio Kecukupan Modal Perbankan yang Terdaftar di Bursa Efek Jakarta. Jurnal Studi Manajemen dan Organisasi, 3(1) : 1-11.

Herry Achmad Buchory. 2014. Analysis of the Effect of Capital, Credit Risk and Profitability to Implementation Banking Intermediation (Study on Regional Development Bank All Over Indonesia Year 2012). International Journal of Business, Economics, and Law, 4(1) : 133-144.

Ikpefan Ochei A. 2013. Capital Adequacy, Management and Performance in the Nigerian Commercial Bank (1986 - 2006). Academic Journals: African Journal of Bussiness Management, 7(30) : 2938-2950.

Kamir. 2014. Bank dan Lembaga Keuangan Lainnya, Edisi Revisi 2014. Jakarta: RajaGrafindo Persada.

Kasmir. 2013. Manajemen Perbankan. Jakarta: RajaGrafindo Persada.

Khaled Abdalla, Moh'd Al-Tamimi, dan Samer Fakhri Obeidat. 2013. Determinants of Capital Adequacy in Commercial Banks of Jordan an Empirical Study. HR Mars: Exploring Intellectual Capital. 2(4) : 44-58.

Krisna, Yansen. 2008. Faktor - Faktor yang Mempengaruhi Capital Adequacy Rati (CAR) (Studi pada Bank - Bank Umum di Indonesia Periode Tahun 2003 - 2006). Tesis. Magister Manajemen pada Universitas Diponegoro. Semarang.

Margaretha, Farah dan Diana Setyaningrum. 2011. Pengaruh Resiko, Kualitas Manajemen, Ukuran dan Likuiditas Bank terhadap Capital Adequacy Ratio Bank-Bank yang Terdaftar di Bursa Efek Indonesia. Jurnal Akuntansi dan Keuangan, 13(1) : 47-56.

Maryam Mushtaq, Aisha Ismail, dan Rahila Hanif. 2015. Credit Risk, Capital Adequacy and Bank's Performance: An Empirical Evidence from Pakistan. International Journal of Financial Management, 5(1) : 27 - 32.

Mei Cai dan Zhonglin Huang. 2014. Analysis Of Non Performing Loan And Capital Adequacy Ratio Among Chinese Banks In The Post-Reform Period In China. ASERS Publishing, 7(30) : 133 - 144.

Nazaf, Feby Loviana. 2014. Pengaruh Kualitas Aset, Likuiditas, dan Profitabilitas terhadap Tingkat Kecukupan Modal Perbankan (Studi Empiris pada Perusahaan Perbankan yang Terdaftar di BEI periode 2008-2012). Jurnal Akuntansi, 2(2) : 1-26 
Nuviyanti dan Achmad Herlanto Anggono. 2014. Determinants of Capital Adequacy Ratio (CAR) in 19 Commercial Banks. Journal of Business and Management, 3(7) : 752-764.

Otoritas Jasa Keuangan. Bank Perkreditan Rakyat. http://www.ojk.go.id/id/kanal/perbankan/Pages/Bank-Perkreditan-

Rakyat.aspx. Diakses pada 22 Juli 2017.

Peraturan Bank Indonesia No.15/12/PBI/2013 tanggal 12 Desember 2013 tentang Kewajiban Penyediaan Modal Minimum Bank Umum

Peraturan Bank Indonesia Nomor 6/10/PBI/2004 tanggal 12 April 2004 tentang Sistem Penilaian Tingkat Kesehatan Bank Umum.

Puspa Yuliani, Kadek., Desak Nyoman Sri Werastuti, dan Edy Sujana. 2015. Pengaruh Loan to Deposit Ratio (LDR), Non Performing Loan (NPL), dan Return on Asset (ROA), dan Operasional terhadap Pendapatan Operasional (BOPO) terhadap Capital Adequacy Ratio (CAR) (Studi pada Bank Umum Swasta Nasionala (BUSN) Devisa). E-Journal Akuntansi S1 Universitas Pendidikan Ganesha, 3(1).

Riyadi, Selamet (2016). Banking Assets And Liability Management, Edisi Keempat, Lembaga Penerbit Fakultas Ekonomi \& Bisnis, Uiniversitas Indonesia.

Romdhane, Mohamed. 2012. The Determinants of Banks' Capital Ratio in Developing Countries: Empirical Evidence from Tunisia. Research Journal of Finance and Accounting, 3(1) : 35-46.

Rubyana Charoline Ningrum, Putu. 2016. Pengaruh CAR dan LDR terhadap Profitabilitas pada PT. BPR MBM di Badung Tahun 2013-2015.Jurnal Program Studi Pendidikan Ekonomi, 8(3) : 1-10.

Sarno, Wiragil. 2017. Bentuk Hukum Badan Usaha Perbankan di Indonesia. http://www.sarno.id/2017/03/bentuk-hukum-badan-usaha-perbankan-diindonesia.html. Diakses 14 Oktober 2017.

Sefri, Lilis Prastya. 2010. Pengaruh Risiko Usaha Terhadap Capital Adequacy Ratio (CAR) Pada Bank Pemerintah. Skripsi. Sekolah Tinggi Ilmu Ekonomi Perbanas Surabaya.

Siamat, Dahlan. 2005. Manajemen Lembaga Keuangan: Kebijakan Moneter dan Perbankan, Edisi Kelima. Jakarta: Lembaga Penerbit Fakultas Ekonomi Universitas Indonesia.

Suad Husnan, Enny Pudjiastuti, 2012. Dasar-Dasar Manajemen Keuangan, Edisi Keenam, Yogyakarta: UPP STIM YKPN. 
Sudirman, I Wayan. 2013. Manajemen Perbankan Menuju Bankir Kovensional yang Profesional, Edisi Pertama. Jakarta: Kencana Prenada Media Group.

Sulistyorini, Yenni. 2011. "Pengaruh LDR, IPR, APB, NPL, BOPO, ROA, AU, IRR, Dan PDN Terhadap Capital Adequacy Ratio (CAR) Pada Bank Umum Nasional Go Public". Skripsi. Sekolah Tinggi Ilmu Ekonomi Perbanas Surabaya.

Surat Edaran Bank Indonesia SE No.13/24/DNDP tanggal 25 Oktober 2011 tentang Penilaian Tingkat Kesehatan Bank Umum.

Surat Edaran Bank Indonesia SE No.6/23/DPNP tanggal 31 Mei 2004 Perihal Sistem Penilaian Tingkat Kesehatan Bank.

Surat Keputusan Direksi BI No. 23/67/KEP/DIR tanggal 28 Februari 1991.

Surat Keterangan Direksi Bank Indonesia No. 26/22/KEP/DIR tanggal 29 Mei 1993 tentang Kualitas Aktiva Produktif dan Pembentukan Penyisihan Aktiva Produktif.

Suvita Jha and Xiaofeng Hui. 2012. A Comparison of Financial Performance of Commercial Banks: A Case Study of Nepal. Academic Journals: African Journal of Bussiness Management, 6(25) : 7601-7611.

Suyana Utama, Made. 2016. Buku Ajar Aplikasi Analisis Kuantitatif. Denpasar: Sastra Utama.

Suyanto, Ali. 2013. Pengelolaan BPR dan Lembaga Keuangan Pembiayaan Mikro. Yogyakarta: Andi Offest.

Undang - Undang Nomor 10 Tahun 1998 tentang Pokok Perbankan, Bank Indonesia. Jakarta.

Veithzal, Rivai, Andria Permata Veithzal, dan Ferry N. Idroes. 2007. Bank and Financial Institution Mangement. Jakarta: Raja Grafindo Persada.

Winda, Ni Made., Parascintya Bukian,dan Gede Merta Sudiartha. 2016. Pengaruh Kualitas Aset, Likuiditas, Rentabilitas dan Efisiensi Operasional terhadap Rasio Kecukupan Modal. E-jurnal Manajemen Unud.5(2) : 1189-1221.

Wulan Suryandani. 2011. Analisis Pengaruh Rasio Kecukupan Modal, Aktiva Produktif, NIM, BOPO dan Likuiditas terhadap Tingkat Return on Asset. Skripsi.Sarjana Ekonomi pada Fakultas Ekonomi Universitas Diponegoro. Semarang.

Yuanjuan, Li and Xiao Shishun. 2012. Effectiveness of China's Commercial Bank's Capital Adequacy Ratio Regulation A Case Study of The Listed Banks. Interdiciplinary Journal of Contemporary Research in Business, 4 (1) : $58-68$. 
E-Jurnal Manajemen Unud, Vol. 7, No. 4, 2018: 1862-1891 